\title{
Seasonal Incidence and Varietal Response of Gram against Helicoverpa armigera (Hubner) at Talwandi Sabo, Punjab
}

\author{
Kulwinder Singh ${ }^{1}$, Anita Singh ${ }^{2 *}$, Jora Singh Brar ${ }^{3}$ \\ ${ }^{1}$ Student, Department of Entomology, University College of Agriculture, Guru Kashi University, Talwandi Sabo, Bathinda \\ Punjab, India \\ ${ }^{2}$ Entomologist, Department of Agriculture, Warkem Biotech Pvt. Ltd., Mumbai, India \\ ${ }^{3} \mathrm{HOD}$, Department of Entomology, University College of Agriculture, Guru Kashi University, Talwandi Sabo, Bathinda \\ Punjab, India
}

*Address for Correspondence: Dr. Anita Singh, Entomologist, Department of Agriculture, Warkem Biotech Pvt. Ltd., L.B.S. Marg, Mumbai, India

E-mail: anita.singh282@gmail.com

Received: 03 Feb 2020/ Revised: 10 May 2020/ Accepted: 22 June 2020

\begin{abstract}
Background: Helicoverpa armigera is considered as a major economical important pest of chickpea throughout the country so the present study was conducted on the seasonal incidence and varietal response of $H$. armigera (gram pod borer) on three varieties i.e. PBG 7, GNG 469 and GPF 2 of chickpea were conducted at Agriculture field of Guru Kashi University, Talwandi Sabo, Punjab during 2017 to 2018.

Methods: The field study on the seasonal incidence and the varietal response of $H$. armigera (gram pod borer) on three varieties i.e. PBG7, GNG469 and GPF2 of chickpea was conducted at Agriculture field of Guru Kashi University, Talwandi Sabo, Punjab during 2017 to 2018.

Results: The first incidence of gram pod borer was started on the first week of December in all selected varieties of a gram. The maximum population of gram pod borer was recorded at flowering and pod formation stage. The pod damage percentage was recorded more in GPF2 followed by GNG469. Minimum pod damage percentage was recorded in PBG7 chickpea variety.

Conclusion: Hence PBG7 shows more resistivity against $H$. armigera followed by GNG469, GPF2.Therefore, this kind of study will motivate the use of more eco-friendly, less toxic control measures to decrease the $H$. armigera population in agriculture field.
\end{abstract}

Key-words: Helicoverpa armigera, Chickpea, Incidence, Pod damage percentage, Varieties

\section{INTRODUCTION}

Cicer arietinum L. (Family: Fabaceae) commonly known as Bengal gram or gram is most economic importance pulse crops, which widely grown throughout the country ${ }^{[1,2]}$. Gram is a good source of protein and known as "a poor man's meat" ${ }^{[3]}$. Major chickpea production constraints are insect pests and diseases under field as well as under storage conditions ${ }^{[4]}$. Out of many insect pests, $H$. armigera is economic importance pest of $C$. arietinum ${ }^{[5]}$. It is polyphagous, cosmopolitan, devastating and worldwide distributed pest ${ }^{[6]}$.

\section{How to cite this article}

Singh K, Singh A, Brar JS. Seasonal Incidence and Varietal Response of Gram against Helicoverpa armigera (Hubner) at Talwandi Sabo, Punjab. SSR Inst. Int. J. Life Sci., 2020; 6(4): 2612-2616.

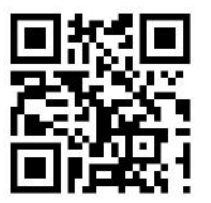

Access this article online https://iijls.com/
The seed yield losses due to $H$. armigera were $75-90 \%$ or at some times causes 90 to $95 \%$ and in some places, the losses were up to $100 \%{ }^{[7,8]}$. The low yield of gram is due to the attack of gram pod borer from the vegetative stage which continues up to the maturity of the crop ${ }^{[9]}$. The larval stage is feeding on flowers and pods of pulses resulting in direct reduction in yield ${ }^{[10]}$. This pest can be controlled by using different integrated methods. In this host plant resistance is a real implement in integrated pest management (IPM) for control of pest as compared to many other control methods ${ }^{[11]}$. Host plant resistance as one of the important component of integrated pest management can play a major role in the management of $H$. armigera ${ }^{[12]}$. This method is reliable, ecologically safe and compatible with other IPM strategies [4]. Therefore the present investigation was conducted on the seasonal incidence and the varietal response of $H$. 
armigera on three different chickpea varieties of chickpea at Talwandi Sabo, Punjab.

\section{MATERIALS AND METHODS}

The present study was conducted at the Guru Kashi University, Talwandi Sabo, Bathinda, Punjab during Rabi season of 2017-18. The site is located at latitude $29^{\circ} 59^{\prime} 0^{\prime \prime} \mathrm{N}$ and longitude $75^{\circ} 5^{\prime} 0^{\prime \prime}$ East, has semi-arid climate with wide variations of summer and winter temperatures. The weather generally remained dry, but from May to August, it was recorded very humid. The rainfall concentrated in July to September.

Preparation of experimental field- The land was given pre-sowing irrigation. It was prepared by using plough followed by a subsequent harrowing. Sowing of three chickpea varieties i.e. GNG469, GPF2 and PBG7 were grown in Randomized block design at an experimental area of Guru Kashi University, Talwandi Sabo by seed drill in line as per agronomical recommendation in 5 rows of 2 meter length with spacing of $30 \mathrm{~cm}$ (row to row) x10 $\mathrm{cm}$ (plant to plant). Two irrigations were done first at 45 days after sowing and second just before flowering stage. The plots were kept free from weeds.

Seasonal incidence of $\boldsymbol{H}$. armigera on Chickpea- Larvae of gram pod borer was recorded on randomly selected plants in the trial plot. The crop was kept free from insecticides. The recording of data started from 15 days after sowing and continued up to crop maturity. The data were collected at weekly interval. The effect of abiotic factors on fluctuation in the incidence of chickpea pod borer was analyzed further. The meteorological observations during the period of investigation were recorded from the observatory of KVK, Bathinda.
Varietal response of chickpea against $\boldsymbol{H}$. armigera- For this observations and recording of data damaged pods with bored holes were collected. Further percentage of pod damage due to $H$. armigera was calculated using the below formula:

\section{Pod damage $(\%)=$ (Number of damaged pods/ Total number of pods) $\times 100$}

Statistical Analysis- The raw data from the field diary was transferred in an electronic format in the spreadsheet layout of Microsoft Excel 2013 and data were analyzed.

\section{RESULTS}

Data recorded on seasonal incidence of $H$. armigera on tender leaves of all three selected genotype (PBG-7, GNG469 and GPF-2) of C. arietinum during 2017-18 are present in Table 1 . At $49^{\text {th }}$ Standard Week (SW) the pest made its first presence on tender leaves with a population of 0.05 larvae per plant on PBG-7, GNG469 and GPF-2. The maximum population was recorded at $4^{\text {th }}$ SW (flowering stage) with 2.8 (PBG-7), 2.9 (GNG469) and 3.15 (GPF-2) larvae per plant respectively. Next pick in larvae population was recorded at $8^{\text {th }} \mathrm{SW}$ (podding stage) with 2.6 (PBG-7), 2.5 (GNG469) and 3.10 (GPF-2) larvae per plant respectively. Simple correlation with weather parameters and larvae population revealed that all three varieties (PBG-7, GNG 469 and GPF-2) was a negative correlation with minimum-maximum temperature and positive correlation was recorded with minimum-maximum relative humidity $(\mathrm{RH})$, whereas the positive correlation was also recorded with rainfall (Table 1).

Table 1: Seasonal Incidence of $H$. armigera on PBG-7, GNG 469 and GPF-2 chickpea genotype during 2017-2018

\begin{tabular}{|c|c|c|c|c|c|c|c|c|c|}
\hline \multirow{2}{*}{$\begin{array}{l}\text { Stander } \\
\text { weather } \\
\text { Week No. }\end{array}$} & \multirow{2}{*}{ Crop Stages } & \multicolumn{3}{|c|}{ *Mean Larval count } & \multicolumn{2}{|c|}{ Temperature $\left({ }^{\circ} \mathrm{C}\right)$} & \multicolumn{2}{|c|}{$\begin{array}{c}\text { Relative } \\
\text { humidity (\%) }\end{array}$} & \multirow[t]{2}{*}{$\begin{array}{l}\text { Rainfall } \\
\text { (mm) }\end{array}$} \\
\hline & & PBG7 & GNG469 & GPF2 & Min & Max & Min & Max & \\
\hline 49 & Vegetative & 0.05 & 0.05 & 0.05 & 4.3 & 24.02 & 78.14 & 36 & 0 \\
\hline 50 & Vegetative & 0.05 & 0.1 & 0.15 & 6.2 & 16.41 & 94.28 & 68.14 & 0.85 \\
\hline 51 & Vegetative & 0.2 & 0.2 & 0.25 & 5.28 & 23.91 & 88.4 & 47.71 & 0 \\
\hline 52 & Vegetative & 0.2 & 0.5 & 0.50 & 4.6 & 22.18 & 92.85 & 45.85 & 0 \\
\hline 1 & Bud Initiation & 0.5 & 0.6 & 1.00 & 3.4 & 15.7 & 95.71 & 66.57 & 0 \\
\hline
\end{tabular}




\begin{tabular}{|c|c|c|c|c|c|c|c|c|c|}
\hline 2 & $\begin{array}{l}\text { Initiation of } \\
\text { Flowering }\end{array}$ & 1.0 & 1.6 & 1.50 & 3.2 & 21.6 & 90.28 & 38.28 & 0 \\
\hline 3 & Flowering & 2.1 & 2.4 & 2.80 & 4.6 & 22.5 & 83.42 & 44.71 & 1.54 \\
\hline 4 & Flowering & 2.8 & 2.9 & 3.15 & 5.41 & 15.7 & 94.42 & 74.28 & 0 \\
\hline 5 & Flowering & 2.7 & 2.5 & 2.50 & 6.11 & 21.4 & 89.57 & 49.43 & 0 \\
\hline 6 & Flowering & 2.3 & 2.1 & 2.15 & 4.41 & 21.3 & 80.71 & 45.14 & 0 \\
\hline 7 & Podding & 2.8 & 2.8 & 2.80 & 7.61 & 22.01 & 87 & 50.21 & 0.31 \\
\hline 8 & Podding & 2.6 & 2.5 & 3.10 & 10.61 & 26.94 & 82.57 & 53.42 & 0 \\
\hline 9 & Grain Filling & 1.5 & 2.0 & 2.10 & 12.2 & 26.91 & 86.28 & 51 & 0 \\
\hline 10 & maturity & 0.1 & 0.1 & 0.15 & 11.47 & 26.62 & 84.42 & 39.14 & 0 \\
\hline 11 & maturity & 0.0 & 0.0 & 0.00 & 14.15 & 30.3 & 77.57 & 39.57 & 0 \\
\hline & & & & PBG7 & -0.054 & -0.17 & 0.011 & 0.26 & 0.1 \\
\hline \multirow{2}{*}{\multicolumn{4}{|c|}{ Correlation value ( $r$ ) for larva Population }} & GNG469 & -0.079 & -0.17 & 0.068 & 0.25 & 0.13 \\
\hline & & & & GPF2 & -0.067 & -0.18 & 0.07 & 0.30 & 0.17 \\
\hline
\end{tabular}

*Mean of randomly selected chickpea plants

Varietal response of chickpea against $\boldsymbol{H}$. armigera- The total average number of damage pods by gram pod borer in variety: PBG7 was 5.3 out of 34.65 average total pods, in GNG469 was 6.85 out of 41.35 average total pods and in GPF2, was 7.7 out of 45.25 average total pods (Table 2), whereas the pod damage percentage was recorded in GPF2 (17.01\%), which was followed by GNG469 (16.56\%) and PBG7 (15.29\%) varieties of chickpea (Table 2).

Table 2: Pod damage percentage on PBG-7, GNG 469 and GPF-2 chickpea genotype during 2017-2018 by H. armigera

\begin{tabular}{ccccccc}
\hline & \multicolumn{7}{c}{ Different Varieties of gram } \\
\cline { 2 - 7 } Plant No. & \multicolumn{2}{c}{ PBG7 } & \multicolumn{2}{c}{ GNG469 } & \multicolumn{2}{c}{ GPF2 } \\
\cline { 2 - 7 } & Total No. of & Damage & Total No. of Pod/ & Damage & Total No. of & Damage \\
Pod/ Plants & Pod & Plants & Pod & Pod/ Plants & Pod \\
\hline 1 & 41 & 15 & 19 & 1 & 47 & 2 \\
2 & 14 & 4 & 31 & 2 & 55 & 5 \\
3 & 46 & 2 & 83 & 1 & 91 & 6 \\
4 & 19 & 4 & 32 & 1 & 48 & 7 \\
5 & 57 & 5 & 30 & 1 & 36 & 3 \\
6 & 27 & 3 & 42 & 6 & 11 & 3 \\
7 & 59 & 2 & 56 & 1 & 23 & 5 \\
8 & 35 & 4 & 28 & 4 & 51 & 2 \\
9 & 14 & 2 & 24 & 1 & 52 & 6 \\
10 & 37 & 12 & 88 & 1 & 38 & 7 \\
11 & 35 & 9 & 19 & 3 & 46 & 1 \\
12 & 17 & 3 & 56 & 9 & 56 & 1 \\
13 & 34 & 7 & 27 & 4 & 90 & 2 \\
14 & 55 & 10 & 38 & 5 & 49 & 1
\end{tabular}




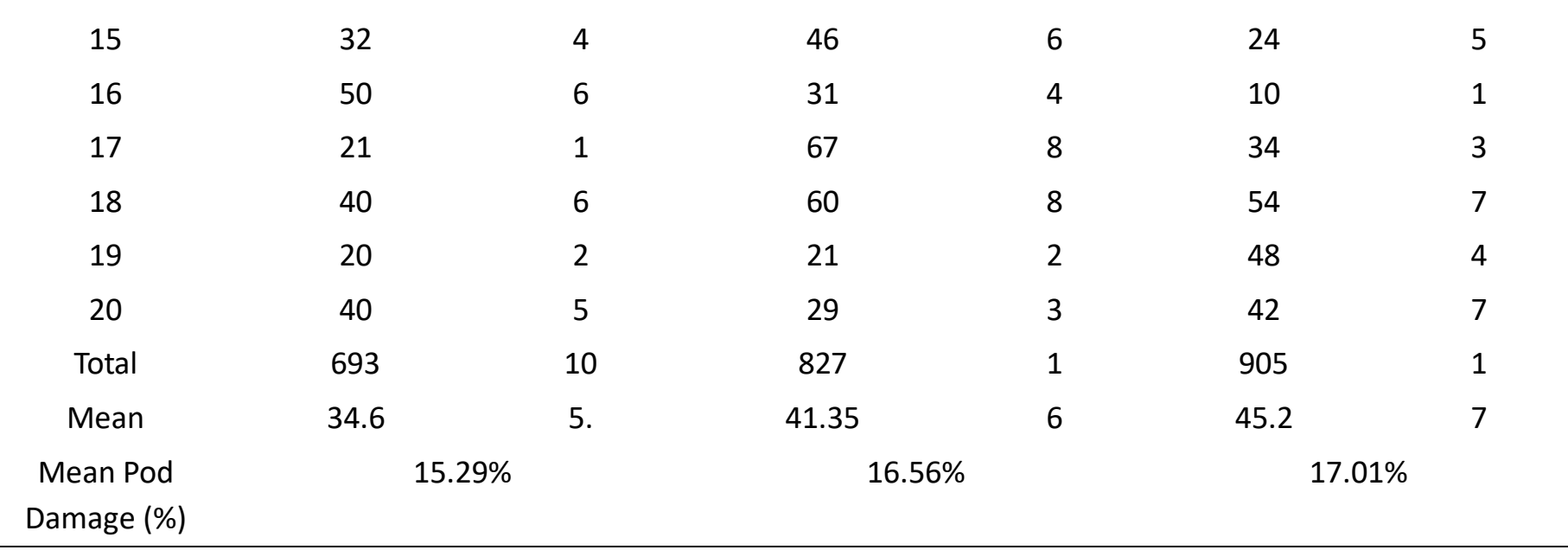

\section{DISCUSSION}

The present results were in close conformity with the result reported earlier at Raipalpur Village, Kanpur the studies on population dynamic of $\mathrm{H}$. armigera revealed that the first incidence was noticed at $44^{\text {th }}$ SW till crop harvest ${ }^{[13]}$. Field experiment at Udaipur Rajasthan recorded the population dynamics of gram pod borer. The result revealed the first incidence in the second week of December. But correlation is conflict with present results as it was showing a positive correlation with temperature and negative correlation with humidity [14]. Field monitoring of gram pod borer at Meerut revealed that pest population first recorded at $52^{\text {nd }}$ week till $15^{\text {th }}$ week, where the temperature is showing positive correction with larval population whereas RH is showing negative correlation with a larval population ${ }^{[15]}$. The population dynamic of gram pod borer was investigated at Bihar Agriculture University revealed that larvae were first arrived at $47^{\text {th }}$ week, where the population is showing significant positive correlation with temperature and negative correlation with $\mathrm{RH}^{[16]}$. In a similar type of study at agriculture research station Badnapur during 2016-17. The seasonal incidence of $H$. armigera on chickpea crop result revealed that the larva population first recorded at $47^{\text {th }} \mathrm{SW}$ to $10^{\text {th }} \mathrm{SW}{ }^{[17]}$.

Many researchers evaluated these resistance varieties against gram pod borer under field condition. Screening of twenty chickpea genotypes including GNG469 against H. armigera on agriculture research farm at the Institute of Agricultural Sciences, Banaras Hindu University recorded $15.49 \%$ pod damage ${ }^{[18]}$. A similar type of experiment conducted in Punjab reported pod borer damage percentage of PBG7 and GPF2 as $15.44 \%$ and $18.50 \%$ respectively ${ }^{[19]}$. Similar type of study revealed that 0.87 mean incidence of $H$. armigera larvae on GNG 469 gram variety ${ }^{[20]}$. At Punjab in similar type of study revealed the $35.4 \%$ incidence of gram pod borer on GPF $2{ }^{[21]}$. Therefore, the present study will help to motivate farmer for using resistant varieties, which are ecofriendly and cost-effective against $H$. armigera.

\section{CONCLUSIONS}

Based on the result, it can be concluded that chickpea pod borer at Talwandi Sabo, Punjab started at $49^{\text {th }}$ week till $11^{\text {th }} \mathrm{SW}$. Pod borer damage percentage was in following sequence GPF2 >GNG469 > PBG7 varieties of chickpea.

Therefore, this study will motivate to develop and use of resistant varieties to minimize the incidence of Pod borer, which is considered as a major pest in the field, which ultimately reduces the use of the toxic chemical.

\section{ACKNOWLEDGMENTS}

Authors are thankful to Dean, University College of Agriculture, Guru Kashi University for the providing facility in the laboratory.

\section{CONTRIBUTION OF AUTHORS}

Research concept- Dr. Jora Singh Brar, Dr. Anita Singh

Research design- Dr. Anita Singh, Dr. Jora Singh Brar

Supervision- Dr. Jora Singh Brar

Materials- Kulwinder Singh

Data collection- Kulwinder Singh

Data analysis and Interpretation- Kulwinder Singh

Literature search- Kulwinder Singh

Writing article- Kulwinder Singh

Critical review- Dr. Jora Singh Brar

Article editing-Dr. Anita Singh

Final approval-Dr. Jora Singh Brar 


\section{REFERENCES}

[1] Verma JP, Yadav J, Tiwari KN. Application of Rhizobium sp. BHURC01 Plant growth promoting rhizobacteria on nodulation, plant biomass and yields of chickpea (Cicer arietinum L.). Int. J. Agric., 2010; 5(3): 148-56.

[2] Pal R, Malik YP, Vikrant, Sharma S, Singh D. Seasonal occurrence of pulse pod borer Helicoverpa armigera (L.) on chickpea at Central U.P. region. J. Pharmacog. Phytochem., 2018; 7(2): 1911-1914.

[3] Zaman K, Shah IA, Khan M M, Ahmad M. Macroeconomic factors determining FDI impact on Pakistan's growth. S. Asian J. Global Bus. Res., 2012; 1(1): 79-95.

[4] Nadeem S, Shafique M, Hamed M, Atta BM, Shah TM. Evaluation of advanced chickpea genotypes for resistance to pod borer, Helicoverpa armigera (Hübner) (Lepidoptera: Noctuidae). Pak. J. Agr. Sci., 2010; 47: 132-35.

[5] Jat SK, Ameta OP. Relative efficacy of biopesticides and newer insecticides against Helicoverpa armigera (Hub.) in tomato. Bioscan., 2013; 8(2): 579-82.

[6] Madhusudan S, Jalali SK, Venkatesan T, Lalitha $Y$, Srinivas RP. 16SrRNA gene based identification of gut bacteria from laboratory and wild larvae of Helicoverpa armigera (Lepidoptera: Noctuidae) from tomato farm. The Bioscan., 2011; 6: 175-83.

[7] Lal SS, Yadav CP, Dias CAR. Assessment of crop losses in chickpea caused by Heliothis armigera. FAO Plant Prot. Bull., 1996; 33: 27-35.

[8] Singh J, Sidhu AS, Kooner BS. Incidence of Heliothis armigera in relation to phenology of chickpeas. J. Res. Punjab Agric. Univ., 1985; 22(2): 291-297.

[9] Dhingra S, Kodandaram RS, Hegde S, Srivastava C. Evaluation of different insecticide mixture against third instar larvae of Helicoverpa armigera. Ann. Plant Protect. Sci., 2003; 11: 274-276.

[10]Srivastava CP, Joshi N, Trivedi TP. Forecasting of Helicoverpa armigera populations and impact of climate change. Indian J. Agr. Sci., 2010; 80 (1): 3-10.

[11]Sharma H, Dhillon M, Arora R. Effects of Bacillus thuringiensis $\delta$-endotoxin fed Helicoverpa armigera on the survival and development of the parasitoid Campoletis chlorideae. Entomol. Exp. Appl., 2008; 126(1): 1-8.
[12]Hossain M A, Haque AA, Prodhan M. Incidence and damage severity of pod borer, Helicoverpa armigera (Hubner) in chickpea (Cicer arietinum L.). Bangladesh J. Sci. Ind. Res., 2009; 44(2): 221-24.

[13]Singh D, Singh SK, Vennila S. Weather parameters influence population and larval parasitization of Helicoverpa armigera (Hubner) in chickpea ecosystem. Legume Res., 2015; 38 (3): 402-06.

[14]Yadav PC, Ameta OP, Yadav SK. Seasonal incidence of gram pod borer, Helicoverpa armigera (Hubner) in chickpea. J. Exp. Zool., 2016; 19 (1): 587-89.

[15]Sardar SR, Bantewad SD, Jayewar NE. Seasonal incidence of Helicoverpa armigera influenced by Desi and Kabuli genotype of Chickpea. Int. J. Curr. Microbiol. App. Sci., 2018; (6S): 536-41.

[16]Spoorthi GS, Singh R, Sachan SK, Singh DV, Sharma R, et al. Monitoring and Seasonal incidence of gram pod borer (Helicoverpa armigera Hubner) in relation to abiotic factor in chickpea. J. Pharmacog. Phytochem., 2017; Sp. (1): 490-94.

[17]Ojha PK, Kumar R, Chaubhay RS. Impact of abiotic and biotic factor on population dynamics of Helicoverpa armigeraHubner (Noctuidae: Lepidoptera) in chickpea. J. Entomol. Zool. Stud., 2017; 5(1): 636-42.

[18]Deepak V, Hiremath, Singh PS, Singh SK. Screening of chickpea genotype against gram pod borer, Helicoverpa armigera Hubner. J Food Legume, 2018; 31 (2): 101-05.

[19]Singh S, Singh I, Sandhu JS, Gupta SK, Bains TS, et al. PBG7: A new high yielding variety of desi gram (Cicer arietinum L.). Agric Res J., 2015; 52(2): 212-13.

[20]Tayade AS. Chickpea varietal response to pod borer, Helicoverpa armigera (Hb). J. Soils Crops, 2010; 20 (1): 174-76.

[21]Cheema H, Singh R, Taggar GK, Sandhu JS, Kooner BS. Screening of chickpea genotypes for resistance against gram pod borer, Helicoverpa armigera (Hubner) under field conditions. Punjab Agric. Univ. J. Res., 2010; 47: 1-3. 